Rhinelander FW. Circulation of bone. In: Bourne GH, ed. The biochemistry and physiology of bone. 2nd ed. Vol. 2 Physiology and Pathology. New York, etc: Academic Press, 1972:2-77.

Riska EB, Von Bonsdorf H, Hakkinen S, et al. Primary operative fixation of long bone fractures in patients with multiple injuries. $J$ Trauma 1977; 17:111-21.

Rokkanen P, Slätis P, Vankka E. Closed or open intramedullary nailing of femoral shaft fractures: a comparison with conservatively treated cases. J Bone Joint Surg [Br] 1969; 51-B:313-23.

Strachan RK, McCarthy I, Fleming R, Hughes SPF. The role of the tibial nutrient artery. J Bone Joint Surg [Br] 1990; 72-B:391-4.

Tothill P, Hooper G, Hughes SP, McCarthy ID. Bone blood flow measured with microspheres: the problem of non-entrapment. Clin Phys Physiol Meas 1987; 8:51-5.

Trias A, Fery A. Cortical circulation of long bones. J Bone Joint Surg $[\mathrm{Am}]$ 1979; 61-A:1052-9.

Trueta J. The role of the vessels in osteogenesis. J Bone Joint Surg [ Br] $1963 ; 45-\mathrm{B}: 402-18$.
Trueta J, Caladias AX. A study of the blood supply of the long bones. Surg Gynecol Obstet 1964; 118:485-98.

Trueta J. Blood supply and the rate of healing of tibial fractures. Clin Orthop 1974; 105:11-26.

Watson-Jones R, Bonnin JG, King T, et al. Medullary nailing of fractures after fifty years: with a review of the difficulties and complications of the operation. J Bone Joint Surg [Br] 1950; 32:694-729.

Wenda K, Ritter G, Degreif J, Rudigier J. Zur genese pulmonaler komplikationen nach marknagelosteosynthesen. Unfallchirurg $1988 ; 91: 432-5$

Willans SM, McCarthy ID. Distributed model of blood-bone exchange. $J$ Biomed Eng 1986; 8:235-43.

Williams JJ, Moalli R, Calista C, Herndon JH. Pulmonary endothelial injury and altered fibrinolysis after femur fracture in rabbits. $J$ Orthop Trauma 1990; 4:303-8.

Zucman J, Maurer P, Berbesson C. Étude experimentale de l'action osteogenique des greffes de perioste, des greffes de moelle osseuse et de l'alesage centro-medullaire. Rev Chir Orthop 1968; $54: 221-38$.

\title{
Metal backing of polyethylene implants
}

The metal backing of polyethylene implants for joint replacement was introduced in 1971 by William $\mathrm{H}$. Harris, who developed an acetabular component with an interchangeable liner to combat anticipated problems with polyethylene wear (Harris 1971). This prosthesis allowed the liner to be changed while leaving a wellcemented metal shell in place. Ten years later, papers from two different centres reported the results of twodimensional finite-element studies of the effects of metal backing on polyethylene implants (Carter, Vasu and Harris 1982; Pedersen et al 1982). Both studies appeared to show that metal backing decreased stresses in the cement and the surrounding bone, reducing the stress concentrations in both. At this time, such stress concentrations were thought to be one of the major causes of loosening of the acetabular cup. As a result of early experience and these studies, a number of different metalbacked polyethylene acetabular components became available. In a parallel development, concerned with the possible late ill-effects of methylmethacrylate cement, cementless fixation of implants became popular despite the lack of any long-term clinical data.

Cementless fixation of an acetabular component makes metal backing a necessity, and this method was apparently successful : early reports at three to five years showed results which seemed to be better than those of cemented acetabular cups and it was generally felt that the problem of acetabular loosening had been solved. In 1987, however, Harris reported the results for his initial

E. M. Keating, MD, Clinical Assistant Professor of Orthopaedic Surgery, LSU Medical School, Shreveport, LA

The Centre for Hip and Knee Surgery, 1199 Hadley Road, Mooresville, Indiana 46158, USA

(C) 1993 British Editorial Society of Bone and Joint Surgery $0301-620 X / 93 / 6701 \$ 2.00$

J Bone Joint Surg [Br] 1993: 75-B :847-8. series after a minimum ten-year follow-up. They showed that $41 \%$ of the acetabular cups had either been revised or needed revision (Harris and Penenberg 1987). Similarly disappointing results were published by Ritter et al (1990); they showed an increased failure rate for metalbacked acetabular cups.

No explanation was available until Livermore et al published their modification of Charnley's technique for the radiographic measurement of polyethylene wear (Charnley and Halley 1975; Livermore, Ilstrup and Morrey 1990). Using this method, Cates et al (1993) were able to determine wear in the group of patients reported by Ritter et al; they found that the linear wear rate of the metal-backed acetabular cups was $0.11 \mathrm{~mm} /$ year compared with $0.08 \mathrm{~mm} /$ year in the non-metal-backed group. This represents a $37 \%$ increase in wear in well-matched series of patients. New finite-element analysis (Dalstra and Huiskes 1991) also indicated that there might be increased stress in the cement of metal-backed components during the stance phase of gait. Several speakers at the recent (1993) meeting of the AAOS reported a relative increase in the incidence of both polyethylene wear and osteolysis after the cementless insertion of metal-backed acetabular components. This is not usually apparent until about six years after insertion, the delay accounting for the satisfactory early and mid-term reports. Some recent investigations in our institution, as yet unpublished, have shown that wear rates may be almost three times higher in cementless than in cemented all-polyethylene cups.

Knee replacement. Based on the arguments applied for cementless hip replacements, cementless metal-backed knee components became available for the tibial and patellar surfaces. At first, these knee replacements were thought to be a considerable improvement but, a few years later, excessive wear was reported for metal-backed patellar components (Bayley et al 1988; Lombardi et al 1988). Metal backing of the tibial component has given no evidence of increased survival, and there have been a 
number of case reports of increased wear, loosening and osteolysis (Engh 1988; Jones et al 1992). Initially, this was thought to be related to the use of heat-pressing to shape the polyethylene liners, but similar failures are being reported for other types of polyethylene (Engh, Dwyer and Hanes 1992). A recent study by Rand (1993) found no difference in survival between metal-backed and all-polyethylene total condylar components. Survival also seems to be related to the congruence of femoral and tibial components, so that it may be several years before the true effect of metal backing in tibial components is clear.

The initial optimism that metal backing would reduce the stresses in polyethylene and increase the

\section{REFERENCES}

Bayley JC, Scott RD, Ewald FC, Holmes GB Jr. Failure of the metalbacked patellar component after total knee replacement. $J$ Bone Joint Surg [Am] 1988: 70-A :668-74.

Carter DR, Vasu R, Harris WH. Stress distributions in the acetabular region. II. Effects of cement thickness and metal backing of the total hip acetabular component. J Biomech 1982; 15:165-70.

Cates HE, Faris PM, Keating EM, Ritter MA. Polyethylene wear in cemented metal-backed acetabular cups. J Bone Joint Surg [Br] 1993 ; 75-B:249-53.

Charnley J, Halley DK. Rate of wear in total hip replacement. Clin Orthop 1975; 112:170-9.

Dalstra M, Huiskes R. The influence of metal backing in cemented cups. Proc 37th annual meeting of the Orthopaedic Research Society, Anaheim, $1991: 272$

Engh GA. Failure of the polyethylene bearing surface of a total knee replacement within four years: a case report. J Bone Joint Surg [Am] 1988; 70-A:1093-6.

Engh GA, Dwyer KA, Hanes CK. Polyethylene wear of metal-backed tibial components in total and unicompartmental knee prostheses. $J$ Bone Joint Surg [Br] 1992; 74-B:9-17.

Harris WH. A new total hip implant. Clin Orthop 1971 : 81 :105-13. longevity of total joint replacements has not been borne out by clinical results. By contrast, evidence is accumulating that metal backing offers no advantages. Many joint-replacement surgeons now feel that much of the increase in consequent wear and osteolysis in cementless replacements may be secondary to poorly fitting liners and to screw holes in the porous-coated metal shells, but there is no direct evidence. The real culprit may be the principle of metal backing for polyethylene. If this is so, it is probable that the present modifications of cementless acetabular, tibial, and patellar components will fail to provide any improvement in wear characteristics.

\section{E. MICHAEL KEATING}

Harris WH, Penenberg BL. Further follow-up on socket fixation using a metal-backed acetabular component for total hip replacement: a minimum ten-year follow-up study. J Bone Joint Surg [Am] 1987; 69-A :1140-3

Jones SMG, Pinder IM, Moran CG, Malcolm AJ. Polyethylene wear in uncemented knee replacements. J Bone Joint Surg [Br] 1992; 74B:18-22.

Livermore J, Ilstrup D, Morrey B. Effect of femoral head size on wear of the polyethylene acetabular component. J Bone Joint Surg [ Am] 1990; 72-A :518-28.

Lombardi AV Jr, Engh GA, Volz RG, Albrigo JL, Brainard BJ. Fracture/ dissociation of the polyethylene in metal-backed patellar components in total knee arthroplasty. J Bone Joint Surg [ Am] 1988; 70A :675-9.

Pedersen DR, Crowninshield RD, Brand RA, Johnston RC. An axisymmetric model of acetabular components in total hip arthroplasty. J Biomech 1982; 15:305-15.

Rand JA. Comparison of metal-backed and all-polyethylene tibial components in cruciate condylar total knee arthroplasty. $J$ Arthroplasty 1993; 8:307-13.

Ritter MA, Keating EM, Faris PM, Brugo G. Metal-backed acetabular cups in total hip arthroplasty. J Bone Joint Surg [Am] 1990; 72A :672-7. 